\title{
Modeling the Influence of Relationship Marketing, Green Marketing and Innovative Marketing on the Business Performance of Small, Medium and Micro Enterprises (SMMES)
}

\author{
*Maziriri ET, Chinomona E \\ Vaal University of Technology, South Africa \\ *chakubvae@hotmail.com
}

\begin{abstract}
Small, Medium and Micro Enterprises (SMMEs) are considered as economic engines for many countries. In South Africa, the Small, Micro and Medium Enterprises (SMMEs) sector has been acknowledged as the driving force to foster economic growth and job creations. This paper aimed at examining how relationship marketing, green marketing and innovative marketing influence the business performance of Small, Medium and Micro Enterprises (SMMEs) in Southern Gauteng, South Africa. The study utilized a quantitative research paradigm. A structured questionnaire consisting of validated scales for relationship marketing, green marketing, innovative marketing and business performance was administered to a sample of 231 SMMEs managerial employees in the Southern Gauteng region of South Africa. Smart PLS was used to analyze the data and the results indicated that there are positive relationships between the posited research variables. Implications of the findings are discussed and limitations and future research directions are alluded to.
\end{abstract}

Keywords: Relationship marketing, Green marketing, Innovative marketing, Business performance, SMMEs

\section{Introduction}

The Small, Micro and Medium Enterprises (SMMEs) sector is crucial for economic growth, employment creation, poverty reduction and reducing levels of inequality (Chimucheka, 2015). Rogerson (2008:307) points out that Small, Medium and Micro Enterprises (SMMEs) play a crucial role in the economic development of a country since they contribute more towards the creation of employment than large companies. This makes it very important for the SMMEs' managers to have a good knowledge of how they can market and run their businesses successfully against the bigger businesses. Kumar (2002) is of the view that the long-term survival of SMMEs may depend on the ability to satisfy customer demands efficiently and effectively. Alafeef (2015) also pointed that businesses make great efforts in their attempt to be more successful in meeting the needs of their consumers than their competitors, consequently to achieve a better position in the market and better business performance. Therefore, in order to compete and survive in a severely competitive global marketplace, it is important for SMMEs managers to resort to relationship marketing, green marketing and innovative marketing. Thus, the objectives of this study were to examine how relationship marketing, green marketing and innovative marketing influence the business performance of Small, Medium and Micro Enterprises (SMMEs) in Southern Gauteng, South Africa.

The growth and survival of SMMEs are threatened by impediments that may exist in the operations and management functional areas of the business. Lack of market research skills has been identified as the one main impediment hindering the success of SMMEs in developing countries (Chimucheka \& Mandipaka, 2015). South African SMMEs are inhibited by factors such as poor marketing skills, lack of marketing research skills, poor analysis of the market, failure to understand and forecast future customer trends and needs and inability to prepare marketing plans. Lekhanya (2010) state that the problems experienced by small business owners in conducting a successful business are market-related issues such as marketing, locality, lack of knowledge of the market, product demand and competition, which are associated with the industry in which the enterprise operates. Maloka (2013) concur that the market related problems that affect SMMEs include issues such as marketing locality, lack of knowledge of the market, product demand and competition which are associated with the industry in which the enterprise operates. In addition, Lekhanya (2010) adds that the management style in small firms often means there is little or no marketing planning and many small business failures result from deficiencies in marketing. 
The major contribution of the paper is that it proposes a framework which will make a positive contribution to the body of knowledge and the growing literature. More precisely, on how relationship marketing, green marketing and innovative marketing can influence the business performance of SMMEs. Although some research has been conducted in the SMME sector, it remains important to also investigate how different conforms of marketing can influence the business performance of SMMEs since, Nickel, McHugh and McHugh (2007) as well as Walsh and Anurit (2008) asserts that lack of marketing and poor marketing are the major reasons for SMMEs' failure. In addition, previous research has examined SMMEs in various contexts by focusing on challenges faced by SMMEs in the Nkonkobe Municipality (Chimucheka \& Mandipaka, 2015); the influence of supplier involvement on communication, relationship longevity and business performance in SMMEs in South Africa (Chinomona \& Hove, 2015).The study on environmental conditions for SMME development in a South African province (Mahadea \& Pillay, 2008), Effects of migration and immigration on SMMEs- the case study of Diepsloot informal settlement, South Africa (Chiloane-Tsoka \& Mmako, 2014), Adapting SMME business functions during economic turmoil (Rootman \& Kruger, 2010) and performance measurement by small and medium enterprises in Cape Metropolis, South Africa. Therefore, the findings of this study will contribute as marketing techniques or guidelines for marketers within SMMEs who seek to improve the business performance of SMMEs.

\section{Literature Review}

Resource-based theory: The use of resource-based theory (RBT) in marketing research has increased by more than $500 \%$ in the past decade, which suggests its importance as a framework for explaining and predicting competitive advantages and performance outcomes (Kozlenkova, Samaha \& Palmatier, 2014). Possibly the biggest contributors to the resource-based theory literature is Wernerfelt (1984) and Barney (1991). Before an elucidation of the theory, it is necessary to define what a resource is. Lamprecht (2011:31) defines a resource as any tangible or intangible asset. In the resource-based theory, a firm is observed as a bundle of resources (Yasuda, 2005). Therefore, this paper adopts resource-based theory as its theoretical framework; because relationship marketing, green marketing and innovative marketing are market-based resources that are critical as well as that an SMME can utilize to improve its business performance. Marketbased resources refer to a subset of firm resources (assets and capabilities) related to marketing activities, such as building brands, relationships, innovations, or knowledge (Kozlenkova, Samaha \& Palmatier, 2014). In this study, the researchers use RBV from the point of view of SMMEs' capabilities, such as building relationship between customers and being innovative.

The resource-based theory (RBT) provides an important framework for explaining and predicting the basis of a firm's competitive advantage and performance (Barney, Ketchen, \& Wright, 2011). Matsoso (2014) concurs that the resource based theory analyses how best certain assets and capabilities of a firm may be utilized and/or lays the basis for competitive advantage. Therefore, firms introduce strategies based on the resources that they control with the aim to enhance efficiency and effectiveness (Barney, 1991). The resource-based theory has in particular become a leading academic theory for explaining business performance (Newbert, 2007). A firm's resources are set to generate a competitive advantage, which in turn offsets performance (Crook, Ketchen, Combs \& Todd, 2008:1142). Zhang, Tansuhaj and Mccullough (2009:294) state that a competitive advantage is the result of a firm that was able to develop resource capabilities progressively and ensured that it was nested within the firm and hard to duplicate. Therefore, capabilities can be considered a significant driver of firm performance (Teece, Pisano \& Shuen, 1997; Makadok, 2001; Zhang et al., 2009). Based on the authors' explanations it can be noted that if the resource based theory is taken into consideration it can enhance the development of SMMEs in Southern Gauteng, South Africa.

Small, medium and Micro Enterprises (SMMEs): For the purpose of this paper, it is crucial to define SMMEs, particularly in the South African perspective. The South African act that provides the regulatory and support framework for SMMEs is the National Small Business Act 102 of 1996, which defines an SMME as a separate and distinct business entity, including cooperative enterprises and non-governmental organizations, managed by one owner or more which including its branches or subsidiaries, if any, predominantly carried on in any sector or subsector of the economy (Maloka, 2013; Chimucheka \& Rungani, 2012). SMMEs comprise an independent property which is individually owned by the owner or manager and which is active in a narrow market place (Fumo \& Jabbour, 2011). The Department of Trade and Industry (DTI) (2010:1) defines SMMEs 
as small corporation entities providing work for a maximum of 100 workers, and 200 workers in the industrial sectors and manufacturing industry. According to Mago and Toro (2013:21) an SMME in South Africa is any business with fewer than 200 employees and an annual turnover of less than 5 million rands, capital assets of less than 2 million rands and the owner is directly involved in the management of the business. The definition for SMMEs encompasses a very broad range of firms, some of which includes formally registered, informal and non-VAT registered organizations (The DTI, 2008:12). In South Africa, a large majority of SMMEs are concentrated on the very lowest end, where survivalist firms are found (Berry 2002). These firms can take the form of street trading enterprises, backyard manufacturing and services, and occasional home-based evening jobs (the Department of Trade and Industry, 2008:12). From the author's elucidations of what an SMME entails it can be noted that an SMME is a business which is individually owned by the owner or manager and which is active in a narrow market place.

Relationship marketing: Relationship marketing was firstly defined (Berry, 1983:1) as an approach followed by organizations to form relationships with customers and to ensure that these relationships are developed and sustained on a continuous basis. According to Van Tonder (2016:291), Grönroos (1994:4) later noted that the aim of relationship marketing is to "to establish, maintain, and enhance relationships with customers and other partners, at a profit, so that the objectives of the parties involved are met". Relationship marketing as such can be viewed as a business strategy aimed at establishing and sustaining long -term relationships with customers that are mutually rewarding and which are achieved through having conversations with customers, treating customers as individual persons and fulfilling promises (Van Tonder, 2016). Lamb, Hair, MacDaniel, Boshoff and Terblanche (2010) advocated that relationship marketing is building a long-term partnership with customers. Chaston (2014) described relationship marketing as a philosophy of creating committed, trusting and cooperative relationships with customers, characterized by openness, genuine concern for the delivery of high-quality services, responsiveness to customer suggestions, fair dealings and willingness to sacrifice short term advantage for long term gains. The successful implementation of relationship marketing necessitates a strategic approach encompassing developing customer-centric processes, selecting and implementing technology solutions, employee empowerment, customer information and knowledge generation capabilities to differentiate them and the ability to learn from best practice (Chaston, 2014). Moreover, successful implementation of relationship marketing ensures long-lasting customer-retention and loyalty (Mohammend \& Rashid, 2012). Ocloo and Tsetse (2013) also add that a retained customer will show resistance to competitors luring.

Green marketing: The progressive development of marketing has seen various definitions of green marketing arise (Dahlstro, 2011). Marketing of ecologically safe and friendly goods is considered green marketing (Minnikova, 2013). Green marketing is a part of the social marketing concept; in other words, it can be defined as the way to understand the needs of customers by means of product, price, promotion and distribution activities and the relationship between planning, practicing and supervising policies which realize the objectives of the organization by minimizing their negative effects on natural environment (Arslan \& Gögce, 2013). According to Maheshwari and Malhotra (2011) the concept of green marketing is the business practice that considers consumers concerns with regards to preservation and conservation of the natural environment. Troup (2010) views green marketing as the use of various marketing activities that encourage the purchase of environmentally preferable products, as well encourage a change in lifestyles. Green marketing is the planning, development and promotion of products or services that satisfy the needs of consumers in quality, output, accessible prices and service, without however a negative effect on the environment with regard to the use of raw material and the consumption of energy (Dileep, 2013; Grant, 2008; Pride \& Ferrell, 2008; Peattie \& Grane, 2006). Moreover, Ottman, Strafford and Hartman (2006:24) indicate that green marketing must adhere to two objectives to be effective, namely improving environmental quality and customer satisfaction. Thus, for the purpose of this paper the term green marketing will be described as the business practice that considers consumers concerns with regards to the preservation and conservation of the natural environment.

Innovative marketing: Innovative marketing means tapping into the potential for new markets, or changing to new products, procedures or systems to meet customer demands (Wu \& Lin, 2014). O'Dwyer, Gilmore and Carson (2009) explains that innovative marketing involves doing something new with ideas, products, 
service, or technology and refining these ideas to a market opportunity to meet the market demand in a new way. Gottlichova and Soukalova (2015:337) points out that innovative marketing is perceived as introducing new methods supporting product sales, improvement in the areas of packaging, advertisement and promotion of products and services. According to Sula and Banyar (2015) innovative marketing is used when all other possibilities of traditional vertical marketing are exhausted. Therefore, the principle of innovative marketing requires a company or a business to constantly search for the real improvements of their products and marketing (Sula \& Banyar, 2015).From the author's explanations it can be noted that innovative marketing is the process where a product is marketed and communicated to the target group by the help of ideas and process which were not used earlier and it is done through changes in the product design, launching the product in a unique place, promoting through unconventional method and uniquely pricing the product.

Business Performance: Understanding the meaning of business performance is a prerequisite for measuring and managing organizational performance (Kotler \& Armstrong, 2011).According to Hove, Sibanda and Pooe (2014:167) business performance refers to how the aggregate technology enabled performance impacts across all firm activities, such as cost reduction, revenue enhancement and competitiveness. Vieira (2010:49) states that business performance might be defined in terms of doing the work, as well as in terms of the results achieved. Reijonen (2008) conducted an empirical study in craft and rural tourism micro business. The author defined business performance as an indicator that measures the business's efficiency and effectiveness in achieving the goals. Business performance can also be analyzed by a business' ability to produce results in relation to set targets (O'Regan, Sims \& Gallear, 2008). Wongrassammee, Gardiner and Simmons (2003) shows that business performance refers to how well the business satisfies the needs of employees, customers and other stakeholders, as well as its ability to achieve its planned business goals. Gibson and Cassar (2005) adopt a similar stance by stating that business performance is concerned with the degree to which the set objectives are achieved. From the above descriptions, it can be noted that business performance involves the effectiveness and efficiency of a business in attaining the set goals and the extent to which the business is able to excel in meeting the needs of all its stakeholders. It therefore suggests that business organizations need to monitor their performance frequently.

Conceptualized Framework: Drawing from the literature reviewed, the research model in Figure 1 has been developed. The conceptual model is a representation of the constructs and their relationships with one another.

Figure 1: Proposed Research framework

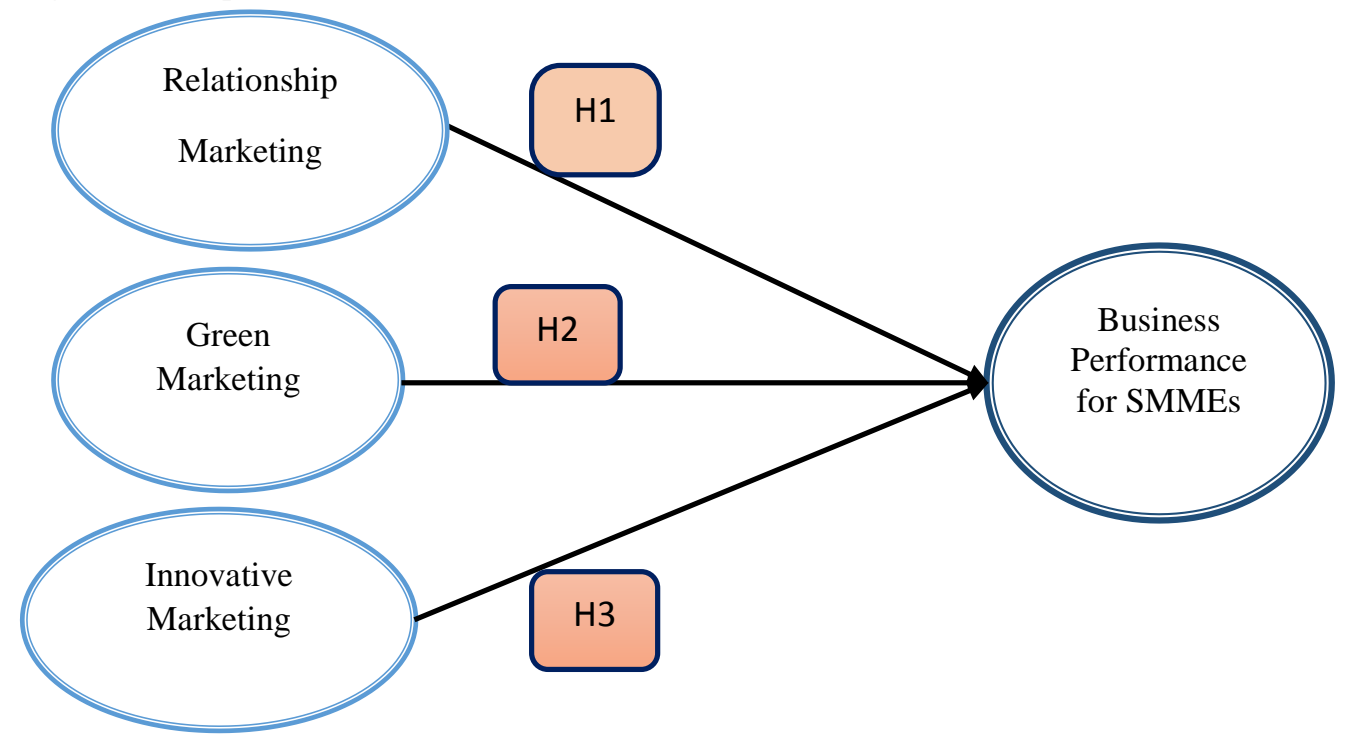


Relationship marketing and business performance: According to Saungweme, Naicker and Chuma (2010) a business that adopts relationship marketing will improve its business performance. Relationship marketing impacts the performance of the organization and increases the financial bottom line (Epetimehin \& Babalola, 2000). In a study conducted by Chahal, Dangwal and Raina (2015) to understanding the role of strategic mix (initiatives) in enhancing relationship marketing practices and business performance, their study' results indicated that the firms that adopt the phenomena of mixed strategies can enhance relationship marketing and ultimately business performance. In addition, most of the research has found that relationship marketing has a positive and significant effect on business performance (Sin, Tse, Yau, Jenny \& Chow, 2002; Gordon, Pires \& Stanton, 2008; Widana, Wiryono, Purwanegara \& Toha, 2015). Drawing from the foregoing discussion, this study therefore, proposes the following hypothesis:

H1: A positive relationship exists between relationship marketing and business performance

Green Marketing and business performance: Green marketing tends to result in the creation of new markets with numerous benefits related to business performance (Chen, 2010). In a study that was conducted by Ogunmokun, Tripolitano, and Rose (2012) in order to investigate whether or not there are significant differences between small business organizations with high versus low levels of green marketing on various aspects of business performance. Their study found that those organizations with high levels of green marketing practices outperformed organizations with low levels of green marketing practices in terms of after tax return on sales; business's total sales growth, overall business's performance, competitive position and market shares. This means that small business organizations who wish to increase their business performance should engage in a high level of green marketing practices (Ogunmokun, Tripolitano \& Rose, 2012).Furthermore, Eneizan, Wahab and Bustaman (2015) indicates the advantages of pursuing green initiatives, such as larger financial gains and market share, high levels of employee commitment, increased firm performance and enhanced capabilities. Thus, this paper hypothesizes that:

H2: A positive relationship exists between green marketing and business performance.

Innovative marketing and business performance: It is by innovation that companies try to improve their business performance and their market share (Alafeef, 2015). Numerous empirical studies have found out that innovative marketing is closely associated with business performance (Gunnar \& Stefansson, 2009; Mukhamad \& Kiminami, 2011; Gunday \& Ulusoy, 2011). Among the studies which support the positive relationship between innovative marketing and business performance is the one conducted by (Haghighinasab, Sattari, Ebrahimi \& Roghanian, 2013). The study provides extra evidence to previous literature that innovative marketing has positive effect on business performance. Hassan, Shaukat, Nawaz, and Naz (2013) study has a strong linkage between innovative marketing and business performance, the authors emphasized that firms bring innovation in their marketing methods to bring efficiency in their business. In light of the above, the paper posits the following:

H3: A positive relationship exists between innovative marketing and business performance

\section{Methodology}

The study utilized a quantitative research design using a structured questionnaire. The design was suitable to solicit the required information relating to innovative marketing, green marketing, relationship marketing and business performance. In addition, the approach enables to examine the causal relationships with the constructs used in the study.

Data collection: The data for this research was collected from SMMEs within the Southern Gauteng province of South Africa. The target population was restricted to Managers, SME owners and Heads of Marketing Departments within SMMEs operating in the Vaal Triangle region of South Africa. The database of the SMMEs (small businesses) was obtained from the Gauteng Enterprise Propeller, the Vaal Triangle business directory as well as 3 Vaal district municipality records as these sources provides more specific SMME data on the Southern Gauteng region.

Measurement instrument and questionnaire design: Research scales were designed on the basis of previous works done. Proper changes were made in order to fit the current research context and purpose. Relationship marketing' was measured using nine-item scales adapted from Eboru (2014:90). Green 
Marketing' used a seven-item scale measure; all were adapted from Li, Ragu-Nathan and Hemantha (2012:89) as well as Ghodeswar and Kumar (2014:59). Innovative marketing used a seven-item scale measure; all were adapted from Wu and Lin (2014:59). Business performance was measured using a four-item scale from Mgxaji (2015:89).All were measured on a five-point Likert-type scale, 1 (strongly disagree) to 5 (strongly agree) in order to express the degree of agreement.

\section{Data Analysis and Results}

Table 1: Sample Description Results

\begin{tabular}{|c|c|c|}
\hline Gender & Frequency & Percentage \\
\hline Male & 138 & $59.7 \%$ \\
\hline Female & 93 & $40.3 \%$ \\
\hline Total & 231 & $100 \%$ \\
\hline Age & Frequency & Percentage \\
\hline Under 30years & 57 & $24.7 \%$ \\
\hline $30-39$ & 83 & $35.9 \%$ \\
\hline $40-49$ & 60 & $26.0 \%$ \\
\hline $50-59$ & 26 & $11.3 \%$ \\
\hline 60 years and above & 5 & $2.2 \%$ \\
\hline Total & 231 & $100 \%$ \\
\hline Highest level of Education & Frequency & Percentage \\
\hline No formal education & 19 & $8.2 \%$ \\
\hline Basic education & 70 & $30.3 \%$ \\
\hline Diploma & 76 & $32.9 \%$ \\
\hline Degree & 55 & $23.8 \%$ \\
\hline Postgraduate or equivalent degree & 11 & $4.6 \%$ \\
\hline Total & 231 & $100 \%$ \\
\hline Number of Employees & Frequency & Percentage \\
\hline Less than 10 employees & 128 & $55.4 \%$ \\
\hline 10 to 50 employees & 53 & $22.9 \%$ \\
\hline 51 to 100 employees & 22 & $9.5 \%$ \\
\hline 101 to 200 employees & 14 & $6.1 \%$ \\
\hline Above 200 employees & 14 & $6.1 \%$ \\
\hline Total & 231 & $100 \%$ \\
\hline
\end{tabular}

The profile of sampled respondents in the survey comprised 138 males and 93 females (representing 59.7\% and $40.3 \%$ respectively). This gender composition tends to suggest that in Southern Gauteng men are substantially more likely to be involved in development of Small, Medium and Micro Enterprises (SMMEs) than women. The age structure of the sample, as illustrated by Table 1, shows that only $24.7 \%(n=57)$ of the respondents were under the age of 30 years, 35.9\% $(n=83)$ were aged between 30 and 39 years, $26.0 \%$ $(n=60)$ represented the $40-49$ year age group, $11.3 \%(n=26)$ represented the $50-59$ year age group and a meagre $2.2 \%(n=5)$ of the sample were 60 years of age and above. The majority $35.9 \%(n=83)$ of the respondents were aged 30-39 years. Therefore it seems that the business leaders within the SMMEs are concentrated within the age bracket of 30-39 years. In terms of formal education levels, Table 1 shows that the majority of the individuals who own or manage SMME businesses had received some basic education $30.3 \%(n=70)$, a diploma $32.9 \%(n=76)$ or a degree $23.8 \%(n=55)$. The remaining $8.2 \%(n=19)$ of the sample represented entrepreneurs who do not have any formal education and $4.6 \% \quad(n=11)$ possessing a postgraduate qualification. The employment figures for this specific sample profile indicate that the majority of the employers are SMME businesses employing fewer than 50 employees per business entity, with $55.4 \%$ in the category, of 10 employees or fewer, $22.9 \%$ of the surveyed employees being in the category of 10 to 50 employees, 9.5\% indicated that their employees are in the category if 51 to 100 employees, $6.1 \%$ indicated 
that there are in the category of 101 to 200 employees and lastly of the participating SMMEs $6.1 \%$ indicated that they employed above 200 employees.

Table 2: Measurement Accuracy Assessment and Descriptive Statistics

\begin{tabular}{|c|c|c|c|c|c|c|c|}
\hline \multirow[t]{2}{*}{ Research constructs } & \multicolumn{2}{|c|}{$\begin{array}{l}\text { Descriptive } \\
\text { statistics* }\end{array}$} & \multicolumn{2}{|c|}{ Cronbach's test } & \multirow[t]{2}{*}{ C.R. } & \multirow[t]{2}{*}{ AVE } & \multirow[t]{2}{*}{$\begin{array}{l}\text { Item } \\
\text { Loadings }\end{array}$} \\
\hline & Mean & SD & $\begin{array}{l}\text { Item- } \\
\text { total }\end{array}$ & $\begin{array}{l}\alpha \\
\text { Value }\end{array}$ & & & \\
\hline \multicolumn{8}{|c|}{$\begin{array}{l}\text { Relationship Marketing } \\
\text { (RM) }\end{array}$} \\
\hline RM3 & 2.90 & 1.188 & 0.531 & 0.825 & 0.826 & 0.610 & 0.536 \\
\hline RM4 & & & 0.610 & & & & 0.619 \\
\hline RM5 & & & 0.660 & & & & 0.663 \\
\hline RM6 & & & 0.699 & & & & 0.742 \\
\hline RM7 & & & 0.741 & & & & 0.747 \\
\hline RM 8 & & & 0.713 & & & & 0.733 \\
\hline RM 9 & & & 0.583 & & & & 0.584 \\
\hline \multicolumn{8}{|l|}{ Green Marketing (GM) } \\
\hline GM 1 & 3.10 & 1.133 & 0.650 & 0.895 & 0.892 & 0.690 & 0.659 \\
\hline GM 2 & & & 0.773 & & & & 0.795 \\
\hline GM 3 & & & 0.749 & & & & 0.863 \\
\hline GM 4 & & & 0.638 & & & & 0.787 \\
\hline GM 5 & & & 0.625 & & & & 0.691 \\
\hline GM 6 & & & 0.681 & & & & 0.684 \\
\hline GM 7 & & & 0.599 & & & & 0.630 \\
\hline \multicolumn{8}{|c|}{ Innovative Marketing (IM) } \\
\hline IM 1 & 3.79 & 1.655 & 0.520 & 0.898 & 0.890 & 0.678 & 0.527 \\
\hline IM 2 & & & 0.749 & & & & 0.753 \\
\hline IM 3 & & & 0.823 & & & & 0.833 \\
\hline IM 4 & & & 0.800 & & & & 0.810 \\
\hline IM 5 & & & 0.811 & & & & 0.824 \\
\hline IM 6 & & & 0.733 & & & & 0.746 \\
\hline IM 7 & & & 0.607 & & & & 0.746 \\
\hline \multicolumn{8}{|c|}{ Business Performance (BP) } \\
\hline BP 1 & 3.03 & 1.300 & 0.605 & 0.825 & 0.826 & 0.600 & 0.617 \\
\hline BP 2 & & & 0.827 & & & & 0.831 \\
\hline BP 3 & & & 0.821 & & & & 0.827 \\
\hline BP 4 & & & 0.803 & & & & 0.822 \\
\hline
\end{tabular}

RM= Relationship Marketing; GM= Green Marketing; IM= Innovative Marketing; BP= Business Performance

On Relationship Marketing 2 items were deleted which is RM 1 and RM 2 due to the fact that the factor loading were less than 0.5 . The lowest item to total loading observed was IM 1 with 0.520 and the highest was IM 3 with 0.823 . The lowest factor loading observed was 0.527 and the highest is 0.863 . This shows that the measurement instruments are valid. The lowest Cronbach alpha was 0.825 and the highest was 0.898 which shows that the constructs were internally consistent or reliable and explained more that $60 \%$ of the variance. All composite reliability values were above the recommended minimum of 0.7 , which shows reliability of the questionnaires used in the study. One of the methods used to ascertain the discriminant validity of the research constructs was the evaluation of whether the correlations among latent constructs were less than 0.60 . These results are reported in Table 3. 
Table 3: Inter-Construct Correlation Matrix

\begin{tabular}{|c|c|c|c|c|c|}
\hline Variables & BP & GM & IM & RM & GS \\
\hline $\mathrm{BP}$ & 0.600 & & & & \\
\hline GM & 0.444 & 0.567 & & & \\
\hline $\mathrm{IM}$ & 0.599 & 0.484 & 0.438 & & \\
\hline $\mathrm{RM}$ & 0.405 & 0.466 & 0.381 & 0.560 & \\
\hline
\end{tabular}

A correlation value between constructs of less than 0.60 is recommended in the empirical literature to confirm the existence of discriminant validity. As can be observed from Table 3, all the correlations were below the acceptable level of 0.60 . Drawing from Table 2 and 3 above, the results further shows the existence of discriminant validity. To ascertain convergent validity, the factor loadings were considered in order to assess if they were above the recommended minimum value of 0.5 . The factor loadings for scale items (Table 2) were above the recommended 0.5 , which indicated that the instruments were valid and converging well on the constructs that they were expected to measure.

Path model results and factor loadings: Below is Figure 2, indicating the path modeling results and as well as the item loadings for the research constructs. In the figure, RM stands for Relationship Marketing; GM stands for Green Marketing; IM is the acronym for Innovative Marketing; BP is the acronym for Business Performance.

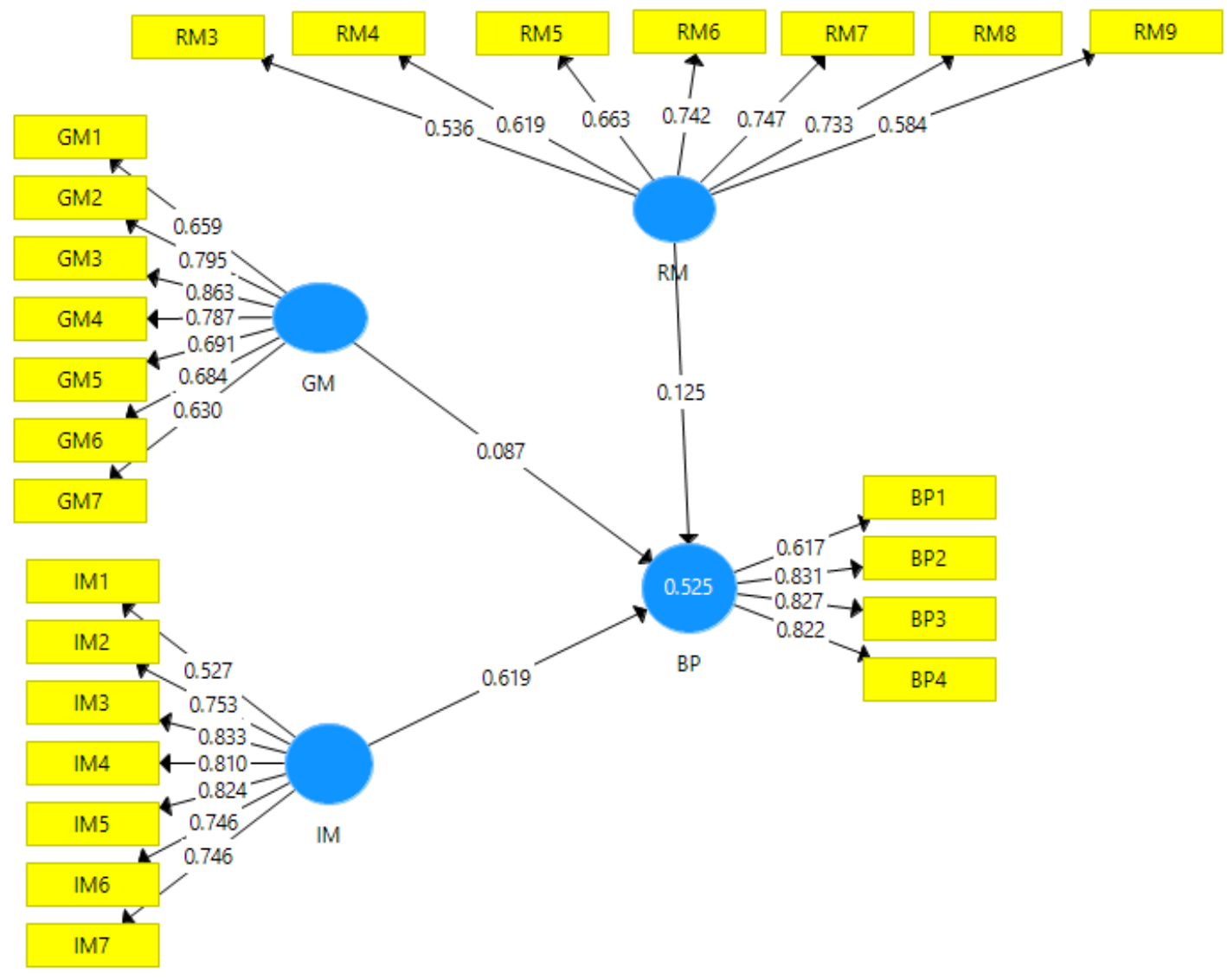


Table 4: Results of structural equation model analysis

\begin{tabular}{llllll}
\hline Path & & Hypothesis & $\begin{array}{l}\text { Path coefficients } \\
(\beta)\end{array}$ & T- Statistics & $\begin{array}{l}\text { Decision on } \\
\text { Hypotheses }\end{array}$ \\
\hline $\begin{array}{l}\text { Relationship Marketing } \\
\rightarrow \text { Business Performance (BP) }\end{array}$ & (RM) & H1 & $0.125^{\mathbf{a}}$ & 1.486 & $\begin{array}{l}\text { Accept/ } \\
\text { Significant }\end{array}$ \\
$\begin{array}{l}\text { Green Marketing (GM) } \rightarrow \text { Business } \\
\text { Performance (BP) }\end{array}$ & $\mathbf{H 2}$ & $0.087^{\mathrm{a}}$ & 1.361 & $\begin{array}{l}\text { Accept/ } \\
\text { Significant }\end{array}$ \\
$\begin{array}{l}\text { Innovative Marketing } \\
\rightarrow \text { Business Performance (BP) }\end{array}$ & (IM) & $\mathbf{H 3}$ & $0.619^{\mathrm{a}}$ & 1.331 & Accept/ \\
$\begin{array}{l}\text { Customer Satisfaction } \\
\rightarrow \text { Customer Loyalty (CL) }\end{array}$ & (CS) & $\mathbf{H 4}$ & $0.534^{\mathrm{a}}$ & 12.989 & Accept/ \\
\end{tabular}

aSignificance Level $\mathrm{p}<.10$; $\mathrm{b}$ Significance Level $\mathrm{p}<.05$; ;ignificance Level $\mathrm{p}<.01$.

Table 4 presents the four hypothesized relationships, path coefficients, the t-statistics and the decision criteria. The value of the t-statistic indicates whether the relationship is significant or not. A significant relationship is expected to have a t-statistics that is above 2. Drawing from the results provided in Table 4, four of the hypothesized relationships (H1, H2 and H3) were statistically significant.

Discussion of Hypotheses Results: The first hypothesis stated that relationship marketing has a positive influence on business performance. In this study, this hypothesis was supported. It can be observed in Figure 2 and Table 4 that relationship marketing exerted a positive influence $(r=0.125)$ and was statistically significant $(t=1.486)$ in predicting business performance. This result suggests that higher the level of relationship marketing the higher the level of business performance in the SMMEs. The second hypothesis suggested that green marketing has a positive influence on business performance. This hypothesis was supported in this study. Figure 1 and Table 4; indicate that this relationship H2 was supported. Green marketing exerted a positive influence $(r=0.087)$ on customer satisfaction and was statistically significant $(\mathrm{t}=$ 1.361). This result denotes that green marketing is positively and significantly related to business performance. Thus higher levels of green marketing will lead to higher levels of business performance. The third hypothesis, which advanced that innovative marketing exerts a positive influence on business performance was supported and accepted in this study. It is reported in Figure 1 and Table 4 that H3 perceived innovative marketing employs a positive $(r=0.619)$ influence on business performance and that this influence is statistically significant $(t=12.989)$. Thus, the more effective the innovative marketing, the greater the business performance of SMMEs.

Limitations and Future Research Direction: A number of limitations were observed during this research. First, the study was restricted to four factors only; namely relationship marketing, green marketing, innovative marketing and business performance of SMMEs. Future research could also include other factors which contribute to effective business performance like good human resource practices in SMMEs. Data was collected from employees in managerial positions only. Future research might try to include views of both non-managerial employees too. This could provide a basis for comparing the views of both managerial and non-managerial employees. Second, the results are based on a small sample of 231 respondents, which makes it difficult to generalize the results to other contexts. Future studies could make use of amplified sample sizes in order to get more representative views. Since this study used a quantitative approach, future studies could also use a mixed method approach so that in depth views of managerial employees can also be captured.

Implications from the study's empirical findings: The present study also offers implications for academicians. Based on the results of the current study innovative marketing is seen to have the strongest influence on the business performance of SMMEs indicated by a path coefficient of 0.619 implying that marketing managers have to ensure that an SMME should have some innovation on its marketing practices in 
order to influence the business performance. As for academicians in the field of marketing this finding enhances their understanding of the relationship between innovative marketing and business performance as this is a useful contribution to existing literature on these two variables.

\section{Conclusion and Managerial Implications}

The study validates that factors such as relationship marketing, green marketing and innovative marketing are instrumental stimulating the business performance of SMMEs in the Southern Gauteng province. The study further validates that SMMEs engaging in relationship marketing, green marketing and innovative marketing leads to high business performance. In addition, innovative marketing has a stronger impact on business performance compared to relationship marketing and green marketing. The study has both theoretical and managerial implications. Theoretically, this study makes a noteworthy progression in marketing theory by methodically examining the interplay between relationship marketing, green marketing and innovative marketing on business performance. In this manner, the study is an important contributor to the existing literature on this subject. The study also underwrites a new direction in the research on consumer behavior by opening up a discussion on the importance of marketing practices in the development and improvement of SMMEs in developing countries such as South Africa. On the practical front, since relationship marketing, green marketing and innovative marketing exerted a positive influence on business performance for SMMEs in the Southern Gauteng province. Managers can try to implement policies and practice green marketing, relationship marketing and be innovative to boost the business performance in their SMMEs. Lastly, the study was conducted on a limited sample and within the southern Gauteng. Therefore, this fact naturally limits the extent to which the results of the study may be generalised to other contexts and environments. Perhaps if other academicians would focus on extending the sample as well as other parts of the Gauteng province as well as rest of the provinces within South Africa results may be more insightful.

\section{References}

Alafeef, M. A. M. I. (2015). The Impact of Innovation Marketing Orientation in Achieving the Competitive Advantage in Hotel Establishments in Saudi Arabia Case Study-Al Baha City-KSA. International Journal of Scientific \& Technology Research, 4(3), 193-198.

Armstrong, G. \& Kotler, P. (2011). Introduction to Marketing. London. Prentice Hall.

Arslan, B. \& Gögce, H. (2013). In the framework of green marketing activities: a study to determine the tendencies of university students towards using environment-friendly products. International Journal of Information Technology and Business Management, 29(19), 16-27.

Barney, J., Ketchen, D. \& Wright, M. (2011). The future of resource based theory: Revitalization or decline? Journal of Management, 37(5), 1299-1315.

Barney, J. B. (1991). Firm resources and sustained competitive advantage. Journal of Management, 17(1), 99120.

Berry, A. E. (2002). The Economics of SMMEs in South Africa. Pretoria: Trade and Industry Policy Strategies.

Berry, L. L. (1983). Relationship marketing. In L. L. Berry, G. L. Shostack, \& G. D. Upah (Eds.), emerging perspectives of services marketing. Chicago, IL: American Marketing Association.

Chahal, Dangwal \& Raina. (2015). Understanding the role of strategic mix (initiatives) in enhancing relationship marketing practices and business performance: A case of SMEs in Jammu District. International Journal of Applied Business and Economic Research, 13(3), 1191-1211.

Chaston, I. (2014). Small Business Marketing. 2rd edition. Palgrave Macmillan. New York.

Chen, Y. S. (2010). The drivers of green brand equity: Green brand image, green satisfaction, and green trust. Journal of Business Ethics, 93(2), 307 -319

Chiloane-Tsoka, E. \&Mmako, N. (2014). Effects of migration and immigration on SMMEs: the case study of Diepsloot informal settlement, South Africa, Problems and Perspectives in Management, 12(4), 377383.

Chimucheka, T. \& Rungani, S. (2012). Obstacles to Accessing Finance by Small Business Operators in the Buffalo City Metropolitan Municipality. Economic Research Southern Africa, Presentation for the African Development Finance Workshop University of Stellenbosch Business School, Cape Town South Africa , August 7-8, 2012. 
Chimucheka, T. \& Mandipaka, F. (2015). Challenges Faced By Small, Medium and Micro Enterprises in the Nkonkobe Municipality. The International Business \& Economics Research Journal, 14(2), 309 -316.

Chimucheka, T. (2015). The Contribution of Entrepreneurship Education in Improving Entrepreneurial Skills and Knowledge of SMME Owners and Managers. Journal of Economics, 6(2), 149-155.

Chinomona, R. \& Hove, P. (2015). The Influence of Supplier Involvement on Communication, Relationship Longevity and Business Performance in Small, Medium and Micro Enterprises in South Africa. Journal of Economics and Behavioral Studies, 7(3), 63-75.

Crook, T. R., Ketchen-Jr, D. J., Combs, J. G. \& Todd, S. Y. (2008). Strategic resources and performance: A metaanalysis. Strategic Management Journal, 29, 1141- 1154.

Dahlstrom, R. (2011). Green marketing management. International ed. Kentucky, USA: South-Western Cengage Learning.

Dileep, K. M. (2013). Does Green Marketing Works With Consumers? Wulfenia Journal, 20(3), 329-347

Eboru, R. (2014). An investigation into Relationship Marketing in South African Family Businesses. Master of Management in Strategic Marketing, University of the Witwatersrand, Johannesburg.

Eneizan, B. M., Wahab, K. A. \& Bustaman, U. S. A. (2015). Effects of green marketing strategy 4ps on firm performance. International Journal of Applied Research, 1(12), 821-824.

Epetimehin, F. M. \& Babalola, J. A. (2000). The Impact of Relationship Marketing on the Performance of Insurance Organisation. Recent Researches in Social Science, 1(2), 1-24.

Fumo, N. D. \& Jabbour, C. J. (2011). Barriers faced by MSEs: Evidence from Mozambique. Journal of Industrial Management and Data Systems, 111(6), 849-868.

Ghodeswar, B. M. \& Kumar, P. (2014). A Study of Green Marketing Practices in Indian Companies. International Journal of Applied Management Sciences and Engineering, 1(2), 51-69.

Gibson, B. \& Cassar, G. (2005). Longitudinal analysis of relationships between planning and performance in small firms. Small Business Economics, 25, 207-222.

Gordon, T. L. O., Pires, G. D. \& Stanton, J. (2008). The relationship marketing orientation of Hong Kong financial services industry managers and its links to business performance. Journal of Financial Services Marketing, 13(3), 193-203.

Gottlichova, M. \& Soukalova, R. (2015). Options for innovation of marketing approaches to the market in the non-profit sector. Procedia - Social and Behavioral Sciences, 17(5), 334 - 341.

Grant, J. (2008). Green marketing. Strategic Direction, 24(6), 25-27.

Greenley, G., Hooley, G. \& Saunders, J. (2004). Management processes in marketing planning. European Journal of Marketing, 38(8), 933 - 955.

Grönroos, C. (1994). From marketing mix to relationship marketing: Towards a paradigm shift in marketing. Management Decision, 32(2), 4-20.

Gunday, G. \& Ulusoy, G. (2011). Effects of innovation types on Firm performance. International journal of production economics, 133(2), 662-676.

Gunner, K. \& Stefansson, L. (2009). Performance issues of smart transportation management systems. International Journal of productivity and performance management, 8(1), 58-68.

Haghighinasab, M., Sattari, B., Ebrahimi, M. \& Roghanian, P. (2013). Identification of Innovative Marketing Strategies to Increase the Performance of SMEs in Iran. International Journal of Fundamental Psychology \& Social Sciences, 3(2), 26 -30

Hassan, M. U., Shaukat, S., Nawaz, M. S. \& Naz, S. (2013). Effects of Innovation Types on Firm Performance: an Empirical Study on Pakistan's Manufacturing Sector. Pakistan Journal of Commerce and Social Sciences, 7(2), 243-262.

Hove, P., Sibanda, K. \& Pooe, D., (2014). The impact of Islamic banking on entrepreneurial motivation, firm competitiveness and performance in South African small and medium enterprises. Mediterranean Journal of Social Sciences, 5(15), 165-174.

Kozlenkova, I. V., Samaha, S. A. \& Palmatier, R. W. (2014). Resource-based theory in marketing. Journal of the Academy of Marketing Science, 42(1), 1-21.

Kumar, K. (2002). Market orientation, organizational competencies and performance: An empirical investigation of a path-analytic model. Journal of American Academy of Business, 1(2), 371-376.

Lamb, C. W., Hair, J. F., McDaniel, C., Boshoff, C. \& Terblanche, N. S. (2010). Marketing - South African 4th edition. Cape Town: Oxford University Press Southern Africa.

Lamprecht, J. L. D. (2011). A comparison of the characteristics of internationalizing SMEs in South Africa and the BRIC countries. M.com Dissertation. North West University. Potchefstroom. 
Lekhanya, L. M. (2010). The Use of Marketing Strategies by Small, Medium and Micro Enterprises in Rural KwaZulu-Natal. Doctor of Technology in marketing dissertation. Durban. Durban University of Technology.

Li, M., Dong, Z. Y. \& Chen, X. (2012). Factors influencing consumption experience of mobile commerce: A study from experiential view. Internet Research, 22(2), 120-141.

Lombard, M. R. (2001). The influence of the marketing concept on company performance with specific reference to customer services within the travel agency industry in the Western Cape. Masters Dissertation. Peninsula Technikon. Capetown.

Mago, S. \& Toro, B. (2013). South African Government's Support to Small, Medium Micro-Enterprise (SMMEs): The Case of King William's Town Area. Journal of Economics, 4(1), 19-28.

Mahadea, D. \& Pillay, M. K. (2008). Environmental conditions for SMME development in a South African Province. South African journal of Economic and Management Sciences, 11(4), 431-448.

Maheshwari, A. \& Malhotra, G. (2011). Green Marketing: A Study on Indian Youth. International Journal of Management and Strategy, 2(3), 1-15.

Makadok, R. (2001). Toward a synthesis of the resource-based and dynamic-capability views of rent creation. Strategic Management Journal, 22, 387-401.

Maloka, C. M. (2013). The Contribution of Small, Medium and Micro Enterprises towards Local Economic Development in Mankweng Township, Limpopo Province. Master of Administration in Development, University of Limpopo. Limpopo Turlop.

Matsoso, M. L. (2014). Performance Measures in Supply Chain Management of Small Manufacturing Enterprises. Master of Technology: Cost and Management Accounting Dissertation. Cape Peninsula University of Technology, Cape Town.

Mgxaji, B. (2015). The Predictors of Business Performance in the Investment Management Industry. Master of Management in Strategic Marketing, University of the Witwatersrand, Johannesburg.

Minnikova, M. (2013). The Link between Green Marketing and Firm Performance Specific recommendations based on applying green marketing strategies to better firm performance. Henrietta-Newyork. Rochester Institute of Technology.

Mohammed, A. A. \& Rashid, B. (2012). Customer Relationship Management (CRM) in Hotel Industry: A framework proposal on the relationship among CRM dimensions, Marketing Capabilities, and Hotel performance. International Review of Management and Marketing, 2(4), 220 -230.

Mukhamad, N. \& Kiminami, A. (2011). Innovation, Cooperation, and Business Performance. Journal of agribusiness in developing and emerging economies, 1(1), 75-96.

National Small Business Act 102 of 1996). Available from https://www.thedti.gov.za/sme_development /docs/act.pd (accessed 10 January, 2016).

Newbert, S. L. (2007). Empirical research on the resource-based view of the firm: an assessment and suggestions for future research. Strategic management journal, 28, 121-146.

Nickel, W. G., McHugh, J. M. \& McHugh, S. M. (2007). Understanding business. 8th edition. Boston: McGrawHill.

O'regan, N., Sims, M. A. \& Gallear, D. (2008). Leaders, loungers, laggards: the strategic -planning environment performance relationship re-visited in manufacturing SMEs. Journal of Manufacturing Technology Management, 19(1), 6-21.

Ocloo, C. E. \& Tsetse, E. K. (2013). Customer retention in the Ghanaian mobile telecommunication industry. European Journal of Business and Social Sciences, 2(7), 136-160.

O'Dwyer, M., Gilmore, A. \& Carson, D. (2009). Innovative marketing in SMEs: an empirical study. Journal of Strategic Marketing, 17(5), 383-396.

Ogunmokun, T., Tripolitano, N. \& Rose, S. (2012). An examination of firms environmental marketing practices, sustainability and business performance. International Journal of Humanities and Social Science, 2(3), 49-53.

Ottman, A. J., Strafford, R. E. \& Hartman, L. C. (2006). Avoiding green myopia: Ways to improve consumer appeal for environmentally friendly preferable products. Environment: Science and Policy for Sustainable Development, 48(5), 22-36.

Peattie, K. \& Crane, A. (2006). Green Marketing: Legend, Myth, Farce or. Prophesy? Quality Marketing Research, 8(4), 357-370.

Pride, W. M. \& Ferrell, O. C. (2008). Marketing, 14th edition. New York: Houghton Mifflin. 
Reijonen, H. (2008). Understanding the small business owner: what they really aim at and how this relates to firm performance: a case study in North Karalia, Eastern Finland. Management Research News, 31(8), 616-629.

Rogerson, C. M. (2008). Tracking SMME development is South Africa: Issues of Finance, Training and the regulatory. Urban Forum, 19(1), 1-10.

Rootman, C. \& Kruger, J. (2010). Adapting SMME business functions during economic turmoil. Actacommercii, 10(1), 107-119.

Saungweme, P. W., Naicker, V. \& Chuma W. (2010). Relationship marketing: Strategic and tactical challenges for SMEs. African journal of business management, 4(13), 2596-2603.

Sin, L. Y. M., Tse, A. C. B., Yau, O. H. M., Jenny, S. Y. L. \& Chow, R. (2002). The effect of relationship marketing orientation on business performance in a service-oriented economy. Journal of Services Marketing, 16(7), 656-676.

Sula, T. \& Banyar, M. (2015). Innovative marketing as a tool for building a positive image of an institution of higher education and increasing the competitiveness of its graduates - Analysis of the functional use of projects of the Department of Marketing Communications at the Faculty of Multimedia communications of TBU in Zlin and their potential for integration into the teaching process. ProcediaSocial and Behavioral Sciences, 175(1), 146-153.

Teece, D. J., Pisano, G. \& Shuen, A. (1997). Dynamic capabilities and strategic management. Strategic management Journal, 18(7), 509-533.

The Department of Trade and Industry (DTI). (2008). Annual review of small business in South Africa 20052007. Pretoria: Department of Trade and Industry.

The Department of Trade and Industry (DTI). (2010). Available from http://www.smmes.co.za (accessed 10 January, 2016.

Troup, J. N. (2010). Green marketing perceptions and opinions: An online comparative company case study of communication strategies. Schaltungsdienst Lange, Berlin: Lambert Academic Publishing.

Van Tonder, E. (2016). Trust and Commitment as Mediators of the Relationship between Quality Advice and Customer Loyalty. Journal of Applied Business Research, 32(1), 289-302.

Vieira V. A. (2010). Antecedents and consequences of market orientation: a Brazilian meta-analysis and an international mega-analysis. Brazilian Administration Review, Curitiba, 7, 44-58.

Walsh, J. \&Anurit, P. (2008). Development of excellent entrepreneurs in small and medium enterprises in Laos and Cambodia. GMSARN International Journal, 2(4), 147-156.

Wernerfelt, B. (1984). A resource-based view of the firm. Strategic Management Journal, 5, 171-180.

Widana, G. O., Wiryono, S. K., Purwanegara, M. S. \& Toha, M. (2015). Exploring the impact of Islamic business ethics and relationship marketing orientation on business performance: the Islamic banking experience. Asian Academic of Management Journal, 20(1), 1-25.

Wongrassamee, S., Gardiner, P. D. \& Simmons, J. E. L. (2003). Performance measurement tools: the balanced scorecard and the EFQM excellence model. Measuring Business Excellence, 7(1), 14-29.

Wu, S. I. \& Lin, T. R. (2014). The Influence of Relational Bonds and Innovative Marketing on Consumer Perception- A Study of Theme Parks. Journal of Management and Strategy, 5(4), 54-67.

Yasuda, H. (2005). Formation of strategic alliances in high-technology industries: Comparative study of the resource-based theory and the transaction-cost theory. Technovation, 25, 763-770.

Zhang, M., Tansuhaj, P. \& Mccullough, J. (2009). International entrepreneurial capability: The measurement and a comparison between born global firms and traditional exporters in China. Journal of International Entrepreneurship, 7, 292-322. 